\title{
Genotoxic Potential of the Insecticide Imidacloprid in a Non-Target Organism (Oreochromis niloticus-Pisces)*
}

\author{
Yadira Ansoar-Rodríguez ${ }^{1,2 \#, ~ C i n t y a ~ A . ~ C h r i s t o f o l e t t i ~}{ }^{3}$, Ana Claudia Marcato1, \\ Jorge Evangelista Correia ${ }^{1}$, Odair Correa Bueno4, Osmar Malaspina4, \\ Carmem S. Fontanetti ${ }^{1}$ \\ ${ }^{1}$ UNESP_São Paulo State University, Rio Claro, Brazil \\ ${ }^{2}$ Department of Pharmacology and Toxicology, Pharmacy and Food Institute, University of Havana, Havana, \\ Cuba \\ ${ }^{3}$ UNIARARAS-Hermínio Ometto Foundation, Araras, Brazil \\ ${ }^{4}$ UNESP/CEIS-Center of Study of Social Insects, Rio Claro, Brazil \\ Email: "yansoar@gmail.com
}

Received 12 November 2015; accepted 5 December 2015; published 9 December 2015

Copyright (C) 2015 by authors and Scientific Research Publishing Inc.

This work is licensed under the Creative Commons Attribution International License (CC BY). http://creativecommons.org/licenses/by/4.0/

(c) (7) Open Access

\section{Abstract}

The indiscriminate use of pesticides has become a serious environmental concern. Insecticide imidacloprid (IMI) is the second most widely used pesticides worldwide. In 2010, 1.934 tons of IMI were sold in Brazil, mostly to be used in sugarcane crops. Several studies have detected its presence in the aquatic environment constituting a risk to non-target organisms. The aquatic animals are organisms used for environmental biomonitoring worldwide. They are considered excellent genetic models to detect environmental mutagens. Among animal species, the fish Oreochromis niloticus, commonly known as Nile tilapia, has been used to evaluate DNA damage. The present study therefore evaluated the effect of IMI on the genetic material of Oreochromis niloticus (Pisces) erythrocytes exposed to different concentration $(250 ; 125$ and $62.5 \mu \mathrm{g} / \mathrm{L})$ of IMI used in growing sugarcane. The effect of the IMI was measured using the comet assay and the micronucleus (MN) test, assays that detected genotoxic damage. The results in the comet assay demonstrated that the concentrations tested induced primary damage to DNA. They also proved the occurrence of MN and nuclear abnormalities at the higher concentration used in the micronuclei and other nuclear abnormalities test. The insecticide IMI induced primary DNA damage at all concentrations and

\footnotetext{
Genotoxic potential of the insecticide imidacloprid.

"Corresponding author.
}

How to cite this paper: Ansoar-Rodríguez, Y., Christofoletti, C.A., Marcato, A.C., Correia, J.E., Bueno, O.C., Malaspina, O. and Fontanetti, C.S. (2015) Genotoxic Potential of the Insecticide Imidacloprid in a Non-Target Organism (Oreochromis niloticus-Pisces). Journal of Environmental Protection, 6, 1360-1367. http://dx.doi.org/10.4236/jep.2015.612118 
damage at the chromosomal level at the highest concentration tested. The results of this study show the potential risk of IMI in a non-target organism.

\title{
Keywords
}

\author{
Pesticide, Genotoxicity, DNA Damage, Comet Assay, Micronucleus Test
}

\section{Introduction}

The use of sugarcane as a biofuel has expanded in the last decade and Brazil becomes the largest producer in the world [1]. The increase in sugarcane crops is accompanied by the increase of pesticide consumption. The imidacloprid (IMI; 1-[(6-chloro-3-pyridinylmethyl]-N-nitro-2-imidazolidinimine) belongs to a class of chemical compounds called neonicotinoids that act on the central nervous system of insects and it is the second most used pesticide in the world [2]. In 2010, companies reported sales of 1.934 tons of IMI to the Brazilian Institute of Environment and Renewable Natural Resources, principally for use in sugarcane.

The IMI can persist in soil, with a half-life (28 - 1250 days) highly variable which varies greatly among soil type and other factors [3]. Also, depending on rainfall and soil conditions, $2.4 \%$ to nearly $80 \%$ of the mass of neonicotinoids (including IMI) could make their way into water bodies [4]. Due to its presence in various environments, inhabited by large numbers of organisms, toxicological studies are extremely important. Thus, the use of living organisms (bioindicator), capable of somehow indicating the presence of stresses generated by environmental pollutants [5] [6], is one way to monitor the negative effects in the environment. Due to the presence of significant levels that have been detected in water, it is very important to conduct studies on the effects of IMI on aquatic organisms as bioindicators. Fish are widely used because of capacity to accumulate contaminants and can show physiological, biochemical, histological or differentiated cell response [7]. These organisms may indicate variations in tolerance to environmental conditions created by the use of pesticides, including genetic change, which makes them excellent indicators with a high application for monitoring environmental genotoxicity [8]. Among the most commonly used species of fish is $O$. niloticus, known as Nile tilapia, considered optimal in laboratory studies for its multiple advantages such as a high rate of growth and reproduction, resistance and tolerance in laboratory conditions and adaptation in commercial alimentation [9].

There are many studies in target and non-target organisms, including mammals, birds, fish, insects, crustacean, molluscs and annelids, showing the toxicity of various neonicotinoids used in agriculture [3]. Furthermore, genotoxicology studies using biomarkers of DNA damage are very important. The tests most used to assess DNA damage in fish exposed to pesticides and other environmental contaminants are the comet and micronucleus tests, excellent tool in genotoxicology, both used in this study.

The alkaline single-cell gel electrophoresis assay, better known as the comet assay, detects strand breaks, alkali-labile sites, and delayed-repair sites as initial damage [9]. The micronucleus (MN) test associated with nuclear abnormalities (NAs) has been used for more than 30 years and also is one of the most promising trials in ecotoxicology for damage detection at the chromosomal level [10] [11]. These tests of genotoxicity are recognized due to their robustness, sensitivity and statistical power to evaluate DNA damage.

In this context, the present study provides more information about the effects of the used of this insecticide in non-target organisms, providing important data on ecotoxicological consequences.

\section{Material and Methods}

\subsection{Test Compound-IMI}

The compound used in this study was IMI (1-[(6-chloro-3-pyridinylmethyl]-N-nitro-2-imidazolidinimine; CAS $\mathrm{N}^{\circ} 138261-41-3$; molecular formula $\mathrm{C}_{9} \mathrm{H}_{10} \mathrm{ClN}_{5} \mathrm{O}_{2}$ ), Agricultural Experiment Station-SP, Lot EDE 0036241.

\subsection{Treatment Solution}

The Concentrations of IMI used in the present study for the exposure of O. niloticus were determined through 
concentration used in growing sugarcane [12] and simulating natural insecticide dilution into water resources [3]. The insecticide IMI was applied in water at three concentrations C1 $=250 \mu \mathrm{g} / \mathrm{L}$ twice the concentration to simulate indiscriminate use, $\mathrm{C} 2=125 \mu \mathrm{g} / \mathrm{L}$ based on the maximum concentration of the commercial product applied in sugarcane and C3 $=62.5 \mu \mathrm{g} / \mathrm{L}$, half of the recommended concentration to simulate natural dilution.

\subsection{Biological Material}

The test organism used in the experiment was $O$. niloticus (Perciformes, Cichlidae) $(\mathrm{n}=50)$, popularly known as Nile tilapia. Individuals with a mean size of $12-15 \mathrm{~cm}$ were analysed to avoid intra-specific differences related to size, age (two months) and average body weight (30 $\pm 2 \mathrm{~g}$ ). The individuals analysed were reared on fish culture farms and kept in the Experimental Garden of the Institute of Biosciences, UNESP (São Paulo State University), Rio Claro, São Paulo, Brazil. They were brought to the laboratory and acclimated in aerated aquariums (size: length $=45 \mathrm{~cm}$, height $=25 \mathrm{~cm}$, width $=20 \mathrm{~cm}$ ) for one week at a mean temperature of $23^{\circ} \mathrm{C}$, in tap water $\left(\mathrm{pH}=8.3\right.$, Temp $\left.=20^{\circ} \mathrm{C} \pm 2^{\circ} \mathrm{C}\right)$ and 14 hours light/dark cycle.

\subsection{Bioassay}

Ten aquariums were used in the experiment, two for negative control (NC) (fresh water), two in which animals received an intraperitoneal (i.p.) injection the clastogenic agent cyclophosphamide (20 mg/mL) (in sterile water) (30 $\mathrm{mL}$ of cyclophosphamide/50 g of fish) for the positive control (PC) [13] and the remaining six were exposed to the three IMI concentrations (250; 125 and $62.5 \mu \mathrm{g} / \mathrm{L}$ ). All treatments consisted of two replicates with five organisms, each one in a $40 \mathrm{~L}$ aquarium, which was aerated during the 96h exposure period [13] [14] and no food was supplied to the fish during the experiment. Approximately $0.3 \mathrm{~cm}^{3}$ of whole blood was taken from each fish by heart puncture using heparinised syringes. The collected blood was used for the comet assay and the MN and NA test. The study was approved by "The Ethics Committee on Animal Use", UNESP, filed with the number 8937.

\subsection{Comet Assay}

The alkaline comet assay was performed as described by Collins (2004) with the modifications suggested by Caffetti et al. (2008) [15] [16]. The blood was obtained from the fish as described above and $3 \mu \mathrm{L}$ aliquots were diluted in $1 \mathrm{~mL}$ of PBS (137 mM NaCl, $2.68 \mathrm{mM} \mathrm{KCl}, 8 \mathrm{mM} \mathrm{HNa}_{2} \mathrm{PO}_{4} ; \mathrm{H}_{2} \mathrm{KPO}_{4} 1.47 \mathrm{mM}$ ) to obtain the cell suspension. Microscope slide coded were coated with $1 \%(\mathrm{v} / \mathrm{v})$ standard agarose and $10 \mu \mathrm{L}$ of the diluted blood with $120 \mu \mathrm{l}$ the $0.5 \%(\mathrm{v} / \mathrm{v})$ low melting point agarose were applied to the slides at $37^{\circ} \mathrm{C}$. After, cover slips were placed on the slides for $10 \mathrm{~min}$ at $4^{\circ} \mathrm{C}$ to ensure the formation of the microgel. The slides were placed in lysis buffer (1 mL of Triton X-100, $10 \mathrm{~mL}$ of DMSO, and $89 \mathrm{~mL}$ of solution plus, which included $2.5 \mathrm{M} \mathrm{NaCl}, 100$ mM EDTA, $10 \mathrm{mM}$ Tris, $\sim 8.0 \mathrm{~g}$ of $\mathrm{NaOH}$ and $10 \mathrm{~mL}$ of $1 \%$ (v/v) sodium lauryl sarcosinate), $\mathrm{pH} 10$, in a refrigerator for $1 \mathrm{~h}$. After lysis, the slides were incubated in $300 \mathrm{mM} \mathrm{NaOH}+1 \mathrm{mM}$ EDTA buffer (pH > 13) for 20 min to denature the DNA and then submitted to electrophoresis at $39 \mathrm{~V}$ and $300 \mathrm{~mA}$ for $20 \mathrm{~min}$; field strength $0.8 \mathrm{~V} / \mathrm{cm}$. The slides were then neutralised with PBS for $15 \mathrm{~min}$ and fixed in absolute ethanol for $10 \mathrm{~min}$. The slides were stained with Gel Red Nucleic Acid (Gel Stain Biotum 10,000× water) and analysed (blindly) under an Olympus BX60 fluorescence microscope equipped with filter excitation: $\mathrm{k}=420$ - $490 \mathrm{~nm}$, emission barrier: $\mathrm{k}=520 \mathrm{~nm}$ ) and a $40 \times$ objective lens.

For each fish, 100 nucleoids were analysed per blood sample. The nucleoids were visually classified according to fragment migration as undamaged (class 0 ), slightly damaged (class 1), more damaged (class 2) and highly damaged (class 3) per Caffetti et al. (2008) [16]. This record is linearly related to the frequency of DNA strand breaks in the cell population in a study on a wide range of damage. The primary damage score was calculated in arbitrary units (AU) as the sum multiplying the number of observed nucleoids in each class by the class value $(0,1,2$ or 3$)$. The results were reported as the averages in AU with their corresponding standard error of the mean (SEM).

\subsection{MN and NAs Test}

Approximately $0.3 \mathrm{~cm}^{3}$ of blood from each fish was smeared on a slide coded (blood extensions). Three smears were performed for each exposed individual. The material was fixed in absolute ethanol for $10 \mathrm{~min}$ and dried for 
$24 \mathrm{~h}$. After wards, the material was hydrolysed in $1 \mathrm{~N} \mathrm{HCl}$ for $11 \mathrm{~min}$ in moist chambers at $60^{\circ} \mathrm{C}$. After this, the slides were washed in distilled water and placed in Schiff's reagent for $2 \mathrm{~h}$. A total of 3000 erythrocytes form the fish were analysed (blindly) under an immersion objective (1000X). For the identification of MN, some criteria were adopted according to Huber and Streng (1983) [17], and the NAs were recorded according to the classification of Carrasco et al. (1990) and Bolognesi and Hayashi (2011) [10] [11]. The frequency and SEM values for $\mathrm{MN}$ and other NAs in the cells were quantified.

\subsection{Statistical Analysis}

All data were expressed as the mean \pm SEM. The data do not follow a normal distribution (Shapiro-Wilk) and Kruskal-Wallis test show differences between groups. The results obtained in the comet assay and the MN and NAs test were compared with the NC and all groups by the non-parametric Mann-Whitney test. The program used was the Statistical Package for the Social Sciences for Windows, version 15.0, (SPSS Inc., Chicago, IL, EUA).

\section{Results}

\subsection{Comet Assay}

The results obtained using the comet assay in erythrocytes of $O$. niloticus exposed to different IMI concentrations and their respective NC and PC is presented in Table 1. The primary DNA damage was expressed in AU (means and SEM) and represents strand breaks, alkali-labile sites, and delayed-repair sites as initial damage. The erythrocytes of the NC group show a higher occurrence of classes 0 and 1 presented lower genotoxic damage than those that underwent PC and IMI treatments. Fish injected with cyclophosphamide presented erythrocytes with DNA damage index statistically significant in relation to NC. The erythrocytes observed revealed a higher rate of DNA damage (expressed in AU) in all groups exposed to IMI compared to the NC and did not find statistically significant differences between the AU values obtained in the different IMI concentrations.

\subsection{MN and NAs Test}

The means and SEM of MN and other NAs in erythrocytes of $O$. niloticus exposed to IMI and their respective NC and PC are shown in Table 2. The erythrocytes of the NC group show a low frequency of MN and other NAs. Higher chromosomal damage level was found on the PC, with a frequency of MN statistically significant in relation to NC. Also, statistical differences in MN frequency and some NAs such as blebbed nuclei (BL) and notched nuclei (NT), were observed between NC and the highest IMI concentration.

\section{Discussion}

The impact of IMI use under field conditions has not been well studied. The evaluation of the action of different concentrations of IMI and its consequences on the genetic material of fish is of the utmost importance. The

Table 1. Mean \pm SEM expressed in arbitrary units (AU) of the primary DNA damage in the fish Oreochromis niloticus exposed to three concentrations of IMI and cyclophosphamide.

\begin{tabular}{cccccc}
\hline Groups & \multicolumn{5}{c}{ Classes } \\
\cline { 2 - 6 } & 0 & 1 & 2 & 3 & AU \\
\hline NC $\left(\mathrm{H}_{2} \mathrm{O}\right)$ & $75.1 \pm 7.9$ & $19.7 \pm 4.5$ & $5 \pm 2.8$ & $3.4 \pm 2.0$ & $39.9 \pm 12.4$ \\
PC $(20 \mathrm{mg} / \mathrm{mL})$ & $20.7 \pm 8.0$ & $64.6 \pm 6.4$ & $11.7 \pm 3.8$ & $5.9 \pm 2.0$ & $105.7 \pm 13.8^{*}$ \\
IMI $(250 \mu \mathrm{g} / \mathrm{L})$ & $19.3 \pm 4.5$ & $54.8 \pm 6.7$ & $13.7 \pm 2.5$ & $13.6 \pm 3.9$ & $123 \pm 16.1^{*}$ \\
IMI $(125 \mu \mathrm{g} / \mathrm{L})$ & $28 \pm 7.4$ & $58.6 \pm 5.3$ & $9.3 \pm 2.2$ & $7.5 \pm 1.9$ & $99.7 \pm 13.7^{*}$ \\
IMI $(62.5 \mu \mathrm{g} / \mathrm{L})$ & $36.7 \pm 11.6$ & $35.6 \pm 5.8$ & $17.4 \pm 4.8$ & $12.1 \pm 4.1$ & $106.7 \pm 11.8^{*}$ \\
\hline
\end{tabular}

NC: negative control; PC: positive control (cyclophosphamide); IMI: imidacloprid; AU: arbitrary units; ${ }^{*} \mathrm{p}<0.05$, values statistically significant, compared to negative control with the Mann Whitney test. 
Table 2. Mean \pm SEM of the frequencies of various erythrocyte abnormalities in 3000 erythrocytes from the fish Oreochromis niloticus exposed to three concentrations of imidacloprid (IMI) and cyclophosphamide.

\begin{tabular}{cccc}
\hline \multirow{2}{*}{ Groups } & \multicolumn{3}{c}{ Other nuclear abnormalities } \\
\cline { 2 - 4 } & MN & Blebbed Nuclei & Notched Nuclei \\
\hline NC $\left(\mathrm{H}_{2} \mathrm{O}\right)$ & $1 \pm 0.4$ & $0.4 \pm 0.3$ & $0 \pm 0$ \\
PC $(20 \mathrm{mg} / \mathrm{mL})$ & $3.7 \pm 0.8^{*}$ & $1.1 \pm 0.3$ & $0.5 \pm 0.4$ \\
IMI $(250 \mu \mathrm{g} / \mathrm{L})$ & $2.8 \pm 0.8^{*}$ & $3.1 \pm 1^{*}$ & $3.8 \pm 0.8^{*}$ \\
IMI $(125 \mu \mathrm{g} / \mathrm{L})$ & $1.4 \pm 0.7$ & $2.4 \pm 0.8$ & $2.9 \pm 1.6$ \\
IMI $(62.5 \mu \mathrm{g} / \mathrm{L})$ & $0.8 \pm 0.4$ & $0.4 \pm 0.3$ & $0.7 \pm 0.4$ \\
\hline
\end{tabular}

NC: negative control; PC: positive control (cyclophosphamide); IMI: imidacloprid; MN: frequency of micronuclei; ${ }^{*} \mathrm{p}<0.05$, values statistically sig nificant, compared to negative control with the Mann Whitney test.

imidacloprid is one of the most widely used and sold neonicotinoids for the control of pests in different areas, however, it affects not only insect-pests but also non-target organisms. It can cause toxicity in ecosystem organisms, such as earthworms [18], amphipods, microalgae [19] and crustacean [20] among others. Also, the application of this insecticide has been associated with the death of bees in different regions of the country [21] [22]. Besides toxicity studies, it has been evaluated the genotoxicity in plants and animals. For example, DNA damage and increased frequency of MNs in frogs Hypsiboas pulchellus tadpoles (Anura, Hylidae) [23] and chromosomal aberrations and MNs in Allium cepa and Tradescantia pallida [12], showed genotoxic effects.

Different species of fish are used for evaluating pesticides and the choice of blood (erythrocyte) is made primarily because these cells are easily collected without sacrificing the animal and do not require additional separation methods [24] [25]. The use of different IMI concentrations caused a statistically significant increase ( $<$ $0.05)$ in damage to the DNA molecule. This damage refers to strand breaks, alkali-labile sites, and delayed-repair sites, which indicates the genotoxic potential of the insecticide for this aquatic organism. The comet assay has been widely used in studies with pesticides; such a test was applied to the fish species Channa punctatus (Channidae) when exposed to atrazine. In this paper, the authors observed an increase in DNA damage in the erythrocytes of these fish [26]. The same results were observed in studies with the phorate pesticide, a genotoxic organophosphate, in fingerlings of Labeo rohita (Cyprinidae) [27], and Roundup ${ }^{\circledR}$ herbicide, evaluated in Anguilla anguilla (Anguillidae), also displayed genotoxicity [28]. The results obtained in this study corroborate previous studies with other pesticides and support the claim that the comet assay is a highly sensitive method for the detection of DNA damage induced by environmental pollutants.

With the increased use of pesticides against harmful plants and insects in the last decade, it has been observed that certain agricultural chemicals can cause changes that include the inhibition of cell division, the induction of chromosomal abnormalities and chromosomal damage [29]. Chromosomal aberrations induced by pesticides from different cultures are widely used as an indicator of genetic damage. The MN test associated with NAs is one of the most promising tests in ecotoxicological evaluations and the best one for the observation of damage at the chromosomal level [11]. This assay has been widely applied in measurement studies of genotoxicity of different chemicals in species of fish and the biological monitoring of contaminated areas [30] [31]. Based on the results obtained in this study, IMI caused a dose-dependent increase in the frequency of MN and other NAs as BL and NT, which was statistically significant $(\mathrm{p}<0.05)$ in the highest concentration evaluated $(250 \mu \mathrm{g} / \mathrm{L})$ compared to the NC. The results obtained in this study corroborate other pesticide studies using different species of fish, such as the evaluation of Aficida ${ }^{\circledR}$ and Endosulfan insecticides in fish erythrocytes from Cnesterodon decemmaculatus (Poeciliidae) and Carassius carassius (Cyprinidae) by the MN test [32] [33]. These studies demonstrate the effectiveness of fish and the MN test as a model for the biomonitoring of aquatic ecosystems that may be affected by pesticides.

Different kinds of NAs are frequently observed in fish erythrocytes, although the mechanisms responsible have not been fully explained. The BL often is considered to be indicators of genotoxic damage and other NAs, such as NT nuclei, are mainly associated to cytotoxicity [11].

Several authors confirm that the comet assay is slightly more sensitive than the MN test in detecting early genetic damage. Furthermore, the comet assay identifies repairable DNA lesions; consequently, only a limited por- 
tion of the induced primary DNA damage is assumed to lead to the serious damage represented by MN. The MN test detects unrepaired chromosome breaks while the comet assay detects strand breaks, alkali-liable sites, and delayed-repair sites that may or may not become repaired. A combination of MN test and comet assay enables comparison of the relative sensitivity of the two test systems [34]. A study in tadpole shows that IMI concentrations increased the frequency of primary DNA lesions estimated by comet assay. Additionally, the data revealed that the comet assay was more sensitive than the MN test in detecting early DNA damage when the same IMI concentrations were employed for tadpole exposure [35].

Pesticides can induce oxidative stress by generation of free radicals that interact with cellular membrane cause lipid peroxidation, alternations in membrane fluidity, DNA damage and finally carcinogenic effects [36]. For example, study indicates potential of IMI to develop oxidative stress and DNA damage in silkworms [37]. The significant increase in the lipid peroxidation can be possibly due to the reactive oxygen intermediates (ROS), which may lead to cell apoptosis [38]. Previous investigations have reported the induction lipid peroxidation by other pesticides such as endosulfan [39] and cypermethrin in fish [40].

The IMI has the potential to reach surface waters; it has been estimated to potentially reach such waters in concentrations up to $36 \mu \mathrm{g} / \mathrm{L}$ and has been detected in surface waters at concentrations up to $14 \mu \mathrm{g} / \mathrm{L}$ [41]. Higher concentrations can reach the water after application of this insecticide in crops of sugarcane and cause genotoxic damage to non-target organisms such as fish.

\section{Conclusion}

The results demonstrated that the concentrations tested in the comet assay induced primary damage to the DNA by increasing the frequency of strand breaks and alkali labile sites and increasing the frequency of $\mathrm{MN}$ at the highest concentration tested. Imidacloprid induced primary DNA damage at the concentrations tested and damage at the chromosomal level in the concentration of $250 \mu \mathrm{g} / \mathrm{L}$. The results of this study help illustrate the potential ecological risk of IMI in aquatic environments and indirectly, to human health. The development of strategies for reduction in pesticide application and decreasing its impact on fish and other aquatic animals is necessary. This is a laboratory study previous to other field studies to be performed in areas where is applied this pesticide. While it is impossible to prevent the use of pesticides by humans, it would be beneficial to decrease the doses applied to farmland or to encourage the development of less toxic substances with similar effects that will enable future generations to live in healthier environments.

\section{Acknowledgements}

The authors thank the "Asociación Universitaria Iberoamericana de Postgrado” (AUIP) and the São Paulo Research Foundation (FAPESP, process 2012/50197-2) for financial support and American Journal Experts for providing language help.

\section{References}

[1] Rudorff, B.F.T., Aguiar, D.A., Silva, W.F., Sugawara, L.M., Adami, M. and Moreira, M.A. (2010) Studies on the Rapid Expansion of Sugarcane for Ethanol Production in Sao Paulo State (Brazil) Using Landsat Data. Remote Sensing, 2, 1057-1076. http://dx.doi.org/10.3390/rs2041057

[2] Jeschke, P., Nauen, R., Schindler, M. and Elbert, A. (2011) Overview of the Status and Global Strategy for Neonicotinoids. Journal of Agricultural and Food Chemistry, 59, 2897-2908. http://dx.doi.org/10.1021/jf101303g

[3] Goulson, D. (2013) Review: An Overview of the Environmental Risks Posed by Neonicotinoid Insecticides. Journal of Applied Ecology, 50, 977-987. http://dx.doi.org/10.1111/1365-2664.12111

[4] Kurwadkar, S.T., Dewinne, D., Wheat, R., McGaha, D.G. and Mitchell, F.L. (2013) Time Dependent Sorption Behavior of Dinotefuran, Imidacloprid and Thiamethoxam. Journal of Environmental Science and Health, Part B, 48, 237242. http://dx.doi.org/10.1080/03601234.2013.742412

[5] Carneiro, R.M.A. and Takayanagui, A.M.M. (2009) Estudos sobre bioindicadores vegetais e poluição atmosférica por meio de revisão sistemática da literatura. Revista Brasileira de Ciências Ambientais, 13, 26-44.

[6] Abdel-Mohsien, H.S. and Mahmoud, M.A.M. (2015) Accumulation of Some Heavy Metals in Oreochromis niloticus from the Nile in Egypt: Potential Hazards to Fish and Consumers. Journal of Environmental Protection, 6, 1003-1013. http://dx.doi.org/10.4236/jep.2015.69089

[7] Fontanetti, C.S., Souza, T.S. and Christofoletti, C.A. (2012) Sustainable Water Management in the Tropics and Sub- 
tropics-and Case Studies in Brazil. The Role of Biomonitoring in the Quality Assessment of Water Resources, 3, 9751005.

[8] Yohannes, Y.B., Ikenaka, Y., Saengtienchai, A., Watanabe, K.P., Nakayama, M.M. and Ishizuka, M. (2014) Concentrations and Human Health Risk Assessment of Organochlorine Pesticides in Edible Fish Species from a Rift Valley Lake-Lake Ziway, Ethiopia. Ecotoxicology and Environmental Safe, 106, 95-101. http://dx.doi.org/10.1016/j.ecoenv.2014.04.014

[9] Ng, W.-K. and Romano, N. (2013) A Review of the Nutrition and Feeding Management of Farmed Tilapia throughout the Culture Cycle. Reviews in Aquatic Science, 5, 220-254.

[10] Carrasco, K.R., Tilbury, K.L. and Myers, M.S. (1990) Assessment of the Piscine Micronucleus Test as an in Situ Biological Indicator of Chemical Contaminant Effects. Canadian Journal of Fisheries and Aquatic Sciences, 47, 21232136. http://dx.doi.org/10.1139/f90-237

[11] Bolognesi, C. and Hayashi, M. (2011) Micronucleus Assay in Aquatic Animals. Mutagenesis, 26, 205-213. http://dx.doi.org/10.1093/mutage/geq073

[12] Rodríguez, Y.A., Christofoletti, C.A., Pedro, J., Correa, O.B., Malaspina, O., Costa Ferreira, R.F. and Fontanetti, C.S. (2015) Allium cepa and Tradescantia pallida Bioassays to Evaluate Effects of the Insecticide Imidacloprid. Chemosphere, 120, 438-442. http://dx.doi.org/10.1016/j.chemosphere.2014.08.022

[13] Botelho, R.G., Christofoletti, C.A., Correia, J.E., Ansoar, Y., Olinda, R.A. and Tornisielo, V.L. (2015) Genotoxic Response of Juvenile Tilapia (Oreochromis niloticus) Exposed to Florfenicol and Oxytetracycline. Chemosphere, 132, 206-212. http://dx.doi.org/10.1016/j.chemosphere.2015.02.053

[14] Al-Sabti, K. and Metcalfe, C.D. (1995) Fish Micronuclei for Assessing Genotoxicity in Water. Mutation Research, 343, 121-135. http://dx.doi.org/10.1016/0165-1218(95)90078-0

[15] Collins, A.R. (2004) The Comet Assay for DNA Damage and Repair: Principles, Applications, and Limitations. Molecular Biotechnology, 26, 249-261. http://dx.doi.org/10.1385/MB:26:3:249

[16] Caffetti, J.D., Montovani, M.S., Postori, M.C. and Fenocchio, A.S. (2008) First Genotoxicity Study of Paraná River Water from Argentina Using Cells from the Clam Corbicula fluminea (Veneroida Corbiculidae) and Chinese Hamster (Cricetulus griseus Rodentia, Cricetidae) K1 Cells in the Comet Assay. Genetics and Molecular Biology, 31, 561-565. http://dx.doi.org/10.1590/S1415-47572008000300026

[17] Huber, R., Streng, S. and Bauchinger, M. (1983) The Suitability of the Human Lymphocyte Micronucleus Assay System for Biological Dosimetry. Mutation Research, 111,185-193. http://dx.doi.org/10.1016/0027-5107(83)90062-3

[18] Dittbrenner, N., Moser, I., Triebskorn, R. and Capowies, Y. (2011) Assessment of Short and Long-Term Effects of Imidacloprid on the Burrowing Behaviour of Two Earthworm Species (Aporrectodea caliginosa and Lumbricus terrestris) by Using 2D and 3D Post-Exposure Techniques. Chemosphere, 84, 1349-1355. http://dx.doi.org/10.1016/j.chemosphere.2011.05.011

[19] Maley, O., Roberta, S., Elsa, F. and Polanca, T. (2012) Comparative Toxicity of Imidacloprid and Its Transformation Product 6-Chloronicotinic Acid to Non-Target Aquatic Organisms: Microalgae Desmodesmus subspicatus and Amphipod Gammarus fossarum. Pesticide Biochemistry and Physiology, 104, 178-186. http://dx.doi.org/10.1016/j.pestbp.2012.07.008

[20] Agatz, A., Ashauer, R.D. and Browny, C. (2014) Imidacloprid Perturbs Feeding of Gammarus pulex at Environmentally Relevant Concentrations. Environmental Toxicology and Chemistry, 33, 648-653. http://dx.doi.org/10.1002/etc.2480

[21] Cresswell, J.E., Desneux, N. and van Engelsdorp, D. (2012) Dietary Traces of Neonicotinoid Pesticides as a Cause of Population Declines in Honey Bees: An Evaluation by Hill's Epidemiological Criteria. Pest Management Science, 6, 819-827. http://dx.doi.org/10.1002/ps.3290

[22] Larson, J.L., Redmond, C.T. and Potter, D.A. (2015) Mowing Mitigates Bioactivity of Neonicotinoid Insecticides in Nectar of Flowering Lawn Weeds and Turfgrass Guttation. Pest Management Science, 34, 127-132. http://dx.doi.org/10.1002/etc.2768

[23] Pérez-Iglesias, J.M., Ruiz de Arcaute, C., Nikoloff, N., Dury, L., Soloneski, S., Natale, G.S. and Larramendy, M.L. (2014) The Genotoxic Effects of the Imidacloprid-Based Insecticide Formulation Glacoxan Imida on Montevideo Tree Frog Hypsiboas pulchellus Tadpoles (Anura, Hylidae). Ecotoxicology and Environmental Safety, 104,120-126. http://dx.doi.org/10.1016/j.ecoenv.2014.03.002

[24] Yang, X., Meier, J., Chang, L., Rowan, M. and Baumann, P.C. (2006) DNA Damage and External Lesions in Brown Bullheads (Ameiurus nebulosus) from Contaminated Habitats. Environmental Toxicology and Chemistry, 25, 30353038. http://dx.doi.org/10.1897/05-706R.1

[25] Cavas, T. (2011) In Vivo Genotoxicity Evaluation of Atrazine 332 and Atrazine-Based Herbicide on Fish Carassius auratus Using the Micronucleus Test and the Comet Assay. Food and Chemical Toxicology, 49, 1431-1435. 
http://dx.doi.org/10.1016/j.fct.2011.03.038

[26] Nwani, C.D., Nagpure, N.S., Kumar, R., Kushwahab, B., Kumar, P. and Lakrab, W.S. (2011) Mutagenic and Genotoxic Assessment of Atrazine-Based Herbicide to Freshwater Fish Channa punctatus (Bloch) Using Micronucleus Test and Single Cell Gel Electrophoresis. Environmental Toxicology and Pharmacology, 31, 314-322. http://dx.doi.org/10.1016/j.etap.2010.12.001

[27] Mohanty, G., Mohanty, J., Nayak, A.K., Mohanty, S. and Dutta, S.K. (2011) Application of Comet Assay in the Study of DNA Damage and Recovery in Rohu (Labeo rohita) Fingerlings after an Exposure to Phorate, an Organophosphate Pesticide. Ecotoxicology, 20, 283-292. http://dx.doi.org/10.1007/s10646-010-0580-2

[28] Marques, A., Guilherme, S., Gaivão, I., Santos, M.A. and Pacheco, M. (2014) Progression of DNA Damage Induced by a Glyphosate-Based Herbicide in Fish (Anguilla anguilla) upon Exposure and Post-Exposure Periods-Insights into the Mechanisms of Genotoxicity and DNA Repair. Comparative Biochemistry and Physiology, Part C, 166, 126-133. http://dx.doi.org/10.1016/j.cbpc.2014.07.009

[29] Silva, J., Heuser, V. and Andrade, V. (2003) Biomonitoramento Ambiental. Genetica toxicológica, Alcance, Porto Alegre, 167-170.

[30] Souza, T.S. and Fontanetti, C.S. (2006) Micronucleus Test and Observation of Nuclear Alterations in Erythrocytes of Nile Tilapia Exposed to Waters Affected by Refinery Effluent. Mutation Research, 605, 87-93.

http://dx.doi.org/10.1016/j.mrgentox.2006.02.010

[31] Della Torre, C., Buonocore, F., Frenzilli, G., Corsolini, S., Brunelli, A., Guidi, P., et al. (2015) Influence of Titanium Dioxide Nanoparticles on 2,3,7,8-Tetrachlorodibenzo-p-dioxin Bioconcentration and Toxicity in the Marine Fish European Sea Bass (Dicentrarchus labrax). Environmental Pollution, 196, 185-193. http://dx.doi.org/10.1016/j.envpol.2014.09.020

[32] Candioti, J.V., Soloneski, S. and Larramendy, M.L. (2010) Genotoxic and Cytotoxic Effects of the Formulated Insecticide Aficida $^{\circledR}$ on Cnesterodon decemmaculatus (Jenyns, 1842) (Pisces: Poeciliidae). Mutation Research, 703, $180-186$. http://dx.doi.org/10.1016/j.mrgentox.2010.08.018

[33] Dar, S.A., Yousuf, A.R., Balkhi, M.H., Ganai, F.A. and Bhat, F.A. (2015) Assessment of Endosulfan Induced Genotoxicity and Mutagenicity Manifested by Oxidative Stress Pathways in Freshwater Cyprinid Fish Crucian Carp (Carassius carassius L.). Chemosphere, 120, 273-283. http://dx.doi.org/10.1016/j.chemosphere.2014.07.031

[34] Araldi, R.P., Correa de Melo, T., Mendes, T.B., de Sa Junior, P.L., Nozima, B.H.N., TiemiIto, E., de Carvalho, R.F., de Souza, E.B. and Stocco, R.C. (2015) Using the Comet and Micronucleus Assays for Genotoxicity Studies: A Review. Biomedicine \& Pharmacotherapy, 72, 74-82. http://dx.doi.org/10.1016/j.biopha.2015.04.004

[35] Ruiz de Arcaute, C., Pérez-Iglesia, J.M., Nikoloff, N., Natale, G.S., Soloneski, S. and Larramendy, M.L. (2014) Genotoxicity Evaluation of the Insecticide Imidacloprid on Circulating Blood Cells of Montevideo Tree Frog Hypsiboas pulchellus Tadpoles (Anura, Hylidae) by Comet and Micronucleus Bioassays. Ecological Indicators, 45, 632-639. http://dx.doi.org/10.1016/j.ecolind.2014.05.034

[36] Guney, M., Baha, O., Hilmi, D., Gulnur, T., Seren, G.G., Irfan, A. and Tamer, M. (2007) Fallopian Damage Induced by Organophosphate Insecticide Methyl Parathion, and Protective Effect of Vitamins E and C on Ultrastructural Changes in Rats. Toxicology and Industrial Health, 23, 429-438. http://dx.doi.org/10.1177/0748233707076773

[37] Phugare, S.S., Kalyani, C.D., Gaikwad, B.Y. and Jadhav, P.J. (2013) Microbial Degradation of Imidacloprid and Toxicological Analysis of Its Biodegradation Metabolites in Silkworm (Bombyx mori). Chemical Engineering Journal, 230, 27-35. http://dx.doi.org/10.1016/j.cej.2013.06.042

[38] Shen, H.M. and Liu, Z.G. (2006) JNK Signaling Pathway Is a Key Modulator in Cell Death Mediated by Reactive Oxygen and Nitrogen Species. Free Radical Biology \& Medicine, 40, 928-939. http://dx.doi.org/10.1016/j.freeradbiomed.2005.10.056

[39] Pandey, S., Ahmad, I., Parvez, S., Bin-Hafeez, B., Haque, R. and Raisuddin, S. (2001) Effect of Endosulfan on Antioxidants of Freshwater Fish Channa punctatus Bloch: 1. Protection against Lipid Peroxidation in Liver by Copper Preexposure. Archives of Environmental Contamination and Toxicology, 41, 345-352. http://dx.doi.org/10.1007/s002440010258

[40] Uner, N., Oruc, E.O., Canlim, M. and Sevgiler, Y. (2001) Effects of Cypermethrin on Antioxidant Enzyme Activities and Lipid Peroxidation in Liver and Kidney of the Freshwater Fish, Oreochromis niloticus and Cyprinus carpio (L.). Bulletin of Environmental Contamination and Toxicology, 67, 657-664. http://dx.doi.org/10.1007/s00128-001-0174-z

[41] Jemec, A., Tisler, T., Drobne, D., Sepcic, K., Fournier, D. and Trebse, P. (2007) Comparative Toxicity of Imidacloprid, of Its Commercial Liquid Formulation and of Diazinon to a Non-Target Arthropod, the Microcrustacean Daphnia magna. Chemosphere, 68, 1408-1418. http://dx.doi.org/10.1016/j.chemosphere.2007.04.015 